\title{
Influence of Feeding with Hydroponic Green Fodder from Barley on Meat Quality of
} Chicken-Broilers

\author{
Galina S. TALALAY
}

Ph.D. (in Agricultural Sciences)

Associate Professor

College Teacher

Saint-Petersburg State Agrarian University

2, Petersburg highway, St. Petersburg, 196605, Russian Federation tufanov2010@yandex.ru

Anna R. MATSERUSHKA

Ph.D. (in Agricultural Sciences)

Professor

College Teacher

Saint-Petersburg State Agrarian University

2, Petersburg highway, St. Petersburg, 196605, Russian Federation professoranna@yandex.ru

\section{Roman O. KOLESNIKOV}

Ph.D. (in Veterinary Sciences)

Associate Professor

Faculty of Zoo-engineering and Bio-Technologies

Saint-Petersburg State Agrarian University

2, Petersburg highway, St. Petersburg, 196605, Russian Federation

\section{Dmitriy A. GVOZDARYOV}

Ph.D. (in Economic Sciences)

College Teacher

Saint-Petersburg State Agrarian University

2, Petersburg highway, St. Petersburg, 196605, Russian Federation gdagd2303@rambler.ru

\section{Vitaliy V. MATSERUSHKA}

Postgraduate Student

Saint-Petersburg State Agrarian University

2, Petersburg highway, St. Petersburg, 196605, Russian Federation

\begin{abstract}
Abstract. The work is devoted to studying the effect of a new feed additive on the meat qualities of chickens and the chemical composition of meat. Studies have found that the introduction of the studied additives in feed in the amount of $15-20 \%$ contributed to an increase in live weight, a decrease in the content of internal fat by $0.5-1.3 \%$, an increase in hemoglobin in the blood, vitamin A, carotene, and an improvement in fat exchange in the body of the poultry of the experimental groups, a positive effect on the meat quality of chickens. In order to determine influence of these new feed on the productivity of broiler chickens and their meat qualities, a scientific and economic
\end{abstract}


experiment was carried out on a livestock of 600 heads of broilers of the cross "Ross 308 ". Thus, the introduction of GHF into compound feed for broilers according to the developed technology improves the meat quality of poultry and facilitates the digestibility of other feed.Keywords: new fodder; broilers; productivity; meat quality.

\section{Introduction}

The increase in the production of high-quality meat depends primarily on the availability of fodder and proper feeding. One of the indisputable advantages is the creation of a balanced forage base that meets the modern scientific and practical requirements of the industry. In this regard, the most relevant is the use of green hydroponic feed (GHF) (Soliman, El-Sabrout, 2020)

Based on this, a fundamentally new automated hydroponic system for growing green fodder was developed. The hydroponic installation of a modular design is designed for year-round daily production of cheap, high-quality, environmentally friendly and natural protein-vitamin-mineral supplements, regardless of the time of year, weather and climatic conditions (Kostyuchenko, 2010; Kruglyakov, 1991; Aii et al., 1990).

Hydroponic green food - a natural, fortified food for poultry, in structure, has the simplest and most easily digestible organic components (amino acids, fatty acids, saccharides). That is why when using (GHF), the digestibility of other feeds in the diet improves, the quality indicators of meat products improve and the cost of the diet decreases (Bakay, 1970; Okolelova, 2006; Elbers et al., 1998).

Green feed can be grown from seeds of barley, rye, oat, peas, ranch, vetch, as well as a mixture of legumes and cereals.

For this purpose, we used pure barley grain with a germination rate of $90 \%$.

The hydroponic method of growing green feed involves preparing and germinating of grain and growing of green mass. Weighed dry grain was placed in trays and irradiated with a mercury-quartz bactericidal lamp for 3-10 min. (depending on a lamp power).

After irradiation, the barley grain was soaked in water for 10-15 minutes. After the expiration date, the water was drained, the trays were covered with glass, leaving a gap of 1-2 cm wide, and placed on germination.

The grain was germinated for 2 days, maintaining a certain humidity and temperature. The optimum temperature for barley germination is $21-23^{\circ} \mathrm{C}$. 
In the process of germination, the trays were inspected 2 times a day and, if there is a lack of moisture, the grain is moistened, if there is an excess of moisture - the water is dried. When the sprouts appeared in most of the seeds, the coverings were removed and the trays were put on growing.

For the cultivation of green feed, fluorescent and white lamps were used.

Under the influence of water, heat and light, with the process of photosynthesis, the storage carbohydrate (starch) of cereals is converted into forms easily assimilated by the body, which are a necessary and sufficient material for glucose synthesis.

When germinating grain, not only starch is activated, but also protein (proteins), it starts to perform both a structural and a functional role (converted into enzymes (enzymes), vitamins and hormones). That is why the digestibility of feed improves, their consumption decreases, the immunity of animals is strengthened and productive longevity is prolonged.

Experiments show that more intensive accumulation of nutrients and vitamins in plants occurs when they are illuminated for 18 hours a day. Ready-to-eat green food is grass with a height of $10-15 \mathrm{~cm}$.

The hydroponic method makes it possible to obtain from 5 to $12 \mathrm{~kg}$ of green forage from each kilogram of dry grain of cereals and legumes or their mixture (Chuang et al., 2020).

The primary characteristic of the feed nutritional value is its chemical composition (Matserushka, 2017; Talalay, Matserushka, 2020; Ulrikh et al., 2019).

As a result of a comparative assessment of the nutritional value of GHF, fodder barley, it showed that hydroponic feed exceeds the content of nutrients, vitamins and minerals in terms of a set of indicators (Table 1).

Table 1. Comparative characteristics of the used feed raw materials

\begin{tabular}{lccc}
\multicolumn{1}{c}{ Indicators } & $\begin{array}{c}\text { Hydroponic feed, in 1 kg of } \\
\text { dry matter }\end{array}$ & $\begin{array}{c}\text { Fodder barley, in } \\
1 \mathrm{~kg} \text { of dry } \\
\text { matter }\end{array}$ & $\begin{array}{c}\text { Hydroponic feed in } \% \\
\text { to fodder barley }\end{array}$ \\
\hline Exchange energy, M/J & 12.0 & 10.7 & 112.2 \\
\hline Crude protein, g & 136.87 & 106.15 & 128.83 \\
\hline Lysine, mg & 7.36 & 4.87 & 151.05 \\
\hline Methionine, mg & 2.21 & 1.59 & 139.18 \\
\hline Serine, mg & 5.89 & 0.49 & 1208.41 \\
\hline Cystine, $\mathrm{mg}$ & 1.47 & 1.25 & 118.09 \\
\hline Sugar, g & 206.03 & 5.61 & 3674.06 \\
\hline Crude fat, g & 46.36 & 23.56 & 196.73 \\
\hline Crude fiber, g & 123.62 & 48.26 & 256.15 \\
\hline Crude ash, g & 33.11 & 27.42 & 120.78
\end{tabular}




\begin{tabular}{lccc} 
Calcium, g & 1.47 & 0.79 & 185.58 \\
\hline Phosphorus, g & 4.42 & 3.85 & 114.62 \\
\hline Magnesium, g & 1.47 & 1.05 & 139.68 \\
\hline Sodium, g & 0.25 & 0.11 & 227.44 \\
\hline Zinc, mg & 54.53 & 26.25 & 207.72 \\
\hline Selenium, mg & 0.29 & 0.05 & 649.52 \\
\hline Vitamin B1, mg & 3.68 & 0.78 & 470.67 \\
\hline Vitamin B2, mg & 8.90 & 1.25 & 714.47 \\
\hline Vitamin B6, mg & 8.09 & 1.27 & 637.92 \\
\hline Vitamin E, mg & 25.75 & 13.71 & 187.88 \\
\hline Carotene, mg & 21.12 & 3.25 & 649.52
\end{tabular}

Hydroponic feed has biological value. in comparison with fodder barley, the dry matter of hydroponic feed has an increased content of protein (128.93\%) and fat (196.73\%), in addition biologically active substances (carotene, chlorophyll) and the simplest and easily digestible organic components (amino acids, fatty acids, saccharides) are formed in its structure. That is why the use of (GHF) improves the digestibility of other feeds in the diet, improves the quality indicators of meat products and reduces the cost of the diet (Talalay, Matserushka, 2020; Talalay, Matserushka, 2017).

\section{Methods}

To assess the nutritional value of the new protein-mineral feed on the productivity of broiler chickens, a scientific and economic experiment was conducted on a livestock of 600 broilers of the cross "Ross 308" at the poultry farm "Ostrovskaya" in the Pskov region. During the experiment, the doses of the new feed inclusion in the compound feed recipe on replacing 15 and $20 \%$ of the main feed for broiler chickens with GHF with equivalent protein were studied, their effect on the dynamics of live weight and average daily gain, the safety of chickens, feed costs per $1 \mathrm{~kg}$ of growth.

For this purpose, one-day-old chickens were selected according to the principle of analogs; the control and experimental groups were formed of 200 birds in each one. Broilers in the control group were fed with complete feed. The nutritional value of the feed mixture in the control group corresponded to the standards approved by All-Russian Research and Technological Institute of Poultry. Broiler chickens were grown 35 days on a deep bedding.

In order to study the effect of the new feed additive on the chicken meat quality and meat chemical composition at the end of the scientific and economic experiment, we carried out a control slaughter of a 35-day-old bird, 6 birds from each group (3 cockerels and 3 hens), followed by deboning of carcasses. 
IV International Scientific and Practical Conference "Modern S\&T Equipments and Problems in Agriculture"

The studied additive was introduced into the compound feed recipe of the experimental groups in the amount of 15 and $20 \%$ of the replacement of the main compound feed from five days of age.

\section{Results}

The conducted scientific and economic experience showed that the introduction of $15 \%$ and $20 \%$ of the combined feed in the recipe instead of the main compound feed had a negative impact on the broilers' safety and productivity (Table 2).

Table 2. Productivity of broiler chickens using a new feed supplement

Indicators

\begin{tabular}{|c|c|c|c|}
\hline Indicators & $\begin{array}{l}\text { 1. Control group } \\
\text { compound feed }(\mathrm{CF})\end{array}$ & $\begin{array}{l}\text { 2. Experimental group } \\
\text { CF }-(85 \%)+15 \% \text { GHF }\end{array}$ & $\begin{array}{l}\text { 3. Experimental } \\
\text { group CF - } \\
(\mathbf{7 5 \%})+20 \% \\
\text { GHF }\end{array}$ \\
\hline Keeping for growing, heads & 200 & 200 & 200 \\
\hline Live weight of daily chickens, $g$ & 42 & 42 & 42 \\
\hline Preservation, $\%$ & 97.2 & 98.4 & 98.7 \\
\hline \multicolumn{4}{|l|}{ Live weight of 1 head: } \\
\hline at 7 days of age, $g$ & $157 \pm 4.23$ & $162 \pm 4.33$ & $159 \pm 5.09$ \\
\hline at 21 days of age, $g$ & $801 \pm 6.23$ & $825 \pm 6.78$ & $806 \pm 6.16$ \\
\hline at 35 days of age, $g$ & $2250 \pm 7.19$ & $2306 \pm 7.36$ & $2262 \pm 7.36$ \\
\hline Cost of feed per 1 head, $\mathrm{kg}$ & 3.36 & 3.4 & 3.6 \\
\hline $\begin{array}{l}\text { cost of feed per } 1 \mathrm{~kg} \text { per live weight } \\
\text { gain, } \mathrm{kg}\end{array}$ & 1.84 & 1.54 & 1.64 \\
\hline The average daily gain, $\mathrm{g}$ & 56.4 & 58.2 & 57.8 \\
\hline
\end{tabular}

The increase in live weight of broilers of the experimental groups fed with compound feed with a new feed additive is statistically significant $(\mathrm{P}>>0.001)$. The feed consumption per unit of broiler growth in the experimental groups compared with the control ones decreased. The safety of the chickens fed the new feed was relatively high at over $98.7 \%$.

Our studies have shown that the proteins of the new green hydroponic feed, which also has a number of other positive properties that positively affect the meat quality of broiler chickens, are distinguished by high biological usefulness. Its prime cost is significantly lower compared to compound feed.

In the course of the study, anatomical cutting of the chickens was carried out, and the average carcass weight (ungutted, semi-gutted and gutted), there were determened the mass of individual parts of the carcass (thigh, drumstick, pectoral muscles), the total mass of the pectoral muscles, the ratio of total mass of the extremity muscles to the mass of the pectoral muscles, indicators of the length of the carcass (femur, drumstick bones, keel), the mass of edible and inedible parts of the carcass and their ratio. Based on these measurements, the indices characterizing broiler meat 
productivity were calculated: massiveness index, keel meatiness index, thigh meatiness index, drumstick meatiness index, slaughter yield (Saadaoui et al., 2020).

Indicators of anatomical cutting (Table 3) showed that the use of a new additive in broiler feed has some effect on the slaughter qualities of chickens. Their introduction into the feed in the amount of $15-20 \%$ contributed to an increase in the slaughter yield of the semi-gutted carcass by $1.5-1.7 \%$ and the meatiness indices of the keel, drumstick and thigh, as compared with the control groups, 1.3 $\mathrm{g} / \mathrm{cm}, 0.8 \mathrm{~g} / \mathrm{cm}$, and $1.1 \mathrm{~g} / \mathrm{cm}$ respectively.

Table 3. The effect of feeding GHF on the meat quality of broiler chickens

\begin{tabular}{lccc}
\multicolumn{1}{c}{ Meat quality of chickens } & $\begin{array}{c}\text { 1. Control group } \\
\text { compound feed (CF) } \\
\text { without feed } \\
\text { supplements }\end{array}$ & $\begin{array}{c}\text { 2. Experimental } \\
\text { group CF - } \\
(85 \%)+15 \% \mathrm{GHF}\end{array}$ & $\begin{array}{c}\text { 3. Experimental } \\
\text { group CF - } \\
(75 \%)+20 \% \mathrm{GHF}\end{array}$ \\
\hline Yield of half-gutted carcass, \% & 81.0 & 81.5 & 80.2 \\
\hline Yield of gutted carcass, \% & 61.5 & 61.7 & 62.0 \\
\hline Mass of internal fat, g & 35.0 & 45.0 & 45.0 \\
\hline $\begin{array}{l}\text { \% of internal fat to the mass of semi- } \\
\text { gutted carcass }\end{array}$ & 2.7 & 3.9 & 3.8 \\
\hline $\begin{array}{l}\text { Ratio of edible to inedible parts of a } \\
\text { carcass }\end{array}$ & $1.8: 1$ & $1.7: 1$ & $1.8: 1$ \\
\hline $\begin{array}{l}\text { Meat index g/cm } \\
\text { Keel }\end{array}$ & 11.2 & 10.8 & 10.6 \\
$\quad \begin{array}{l}\text { Drumstick } \\
\text { Thigh }\end{array}$ & 6.0 & 6.0 & 5.8 \\
\end{tabular}

It should be noted that a decrease in the content of internal fat in broilers was by $0.5-1.3 \%$ compared with the control one.

A decrease in the internal fat content in chickens indicates a more efficient use of feed nutrients for the needs of growth and development of the body. Chemical analysis of minced meat of chickens (Table 4) indicates that the studied additive increased the protein content from 19.4-20.7\%, the fat content with the introduction of the additive decreased from 7.4-7.8\% and its introduction had no effect on the amount of mineral elements.

\section{Table 4. Chemical analysis of minced meat of broiler chickens}

\begin{tabular}{lccc} 
& Protein & Fat & Ash \\
\hline 1. Control group compound feed (CF) without feed supplements & 18.8 & 6.8 & 1.0 \\
\hline 2. Experimental group CF $(85 \%)+15 \%$ GHF & 19.4 & 7.4 & 1.0 \\
\hline 3. Experimental group CF $(75 \%)+20 \%$ GHF & 20.7 & 7.8 & 1.0
\end{tabular}


The results of a study on the effect of the use of new feed in feeding on some physiological parameters of broiler chickens had a definite effect on the use of vitamin A and carotene in the broiler organism, as evidenced by the results of analysis of the chicken liver (Table 5).

The introduction into the feed of the studied feed additive in the amount of $15-20 \%$ of the diet contributed to an increase in the liver carotene content in the experimental groups by $3.3-6.1 \mu \mathrm{g} / \mathrm{g}$, vitamin A - by 18.8-20.9 $\mu \mathrm{g} / \mathrm{g}$ in comparison with the control group.

\section{Table 5. The effect of new feed supplement on the content of vitamin A and carotene in}

\section{broiler liver}

Characteristics of feeding chickens in the group

Content in the liver, $\mu \mathrm{g} / \mathrm{g}$

1. Control group compound feed (CF) without feed supplements

vitamin A carotene

\begin{tabular}{lcc} 
& 85.4 & 8.5 \\
\hline 2. Experimental group CF $(85 \%)+15 \%$ GHF & 104.2 & 11.8 \\
\hline 3. Experimental group CF $(75 \%)+20 \%$ GHF & 106.3 & 14.6
\end{tabular}

In an experiment to study the effect on growth and development of broilers of green hydroponic feed and compound feed, an analysis was carried out on the content in the liver of chickens of unsaturated and limiting fatty acids (Table 6).

Table 6. The effect of the new feed additive on the content of fatty acids in the liver The fatty acid content in the liver, $\%$

Characteristics of feeding chickens in
the group

\begin{tabular}{|c|c|c|c|c|c|c|}
\hline $\begin{array}{l}\text { 1. Control group compound feed }(\mathrm{CF}) \\
\text { without feed supplements }\end{array}$ & 0.21 & 25.61 & 2.04 & 20.11 & 14.6 & 0.43 \\
\hline $\begin{array}{l}\text { 2. Experimental group CF } \\
(85 \%)+15 \% \mathrm{GHF}\end{array}$ & 0.15 & 22.22 & 1.78 & 20.77 & 18.66 & 0.69 \\
\hline 3. Experimental group $\mathrm{CF}$ & 0.20 & 24.57 & 1.76 & 21.44 & 15.94 & 0.45 \\
\hline
\end{tabular}

$(75 \%)+20 \% \mathrm{GHF}$

A new feed additive in the feed of $15-20 \%$ led, in comparison with the control group, to an increase in the content of unsaturated fatty acids in the liver of chickens by $0.05-3.54 \%$ with a decrease in the concentration of saturated fatty acids by 0.03-5.06 \%, which indicates an improvement in fat metabolism in the body of a bird. Thus, the concentration of Myristic, Palmitic and Palmitoleic acids decreased by $0.02,4.39$ and $0.38 \%$, and the concentration of Linoleic and Linolenic acids increased by 3.54 and $0.12 \%$, respectively.

To study the oxidizing ability of the blood (the process of oxygen transfer in the body of chickens), which ensures the intensity of redox reactions in the body, as well as the tension of the natural 
defenses of broilers when feeding them a new feed supplement, we conducted studies to determine the hemoglobin content in the blood of chickens (Table 7).

Table 7. The hemoglobin content of blood of chickens treated with new feed supplement

\begin{tabular}{lc}
\multicolumn{1}{c}{ Characteristics of feeding chickens in the group } & Hemoglobin content, mg, $\%$ \\
\hline 1. Control group compound feed (CF) without feed supplements & 8.4 \\
\hline 2. Experimental group CF $(85 \%)+15 \%$ GHF & 9.3 \\
\hline 3. Experimental group CF $(75 \%)+20 \%$ GHF & 9.4
\end{tabular}

Analyzing the research data, it can be noted that the introduction of green hydroponic feed from barley into broiler feed increased the studied parameter in the experimental groups compared with the control from 8.4 to $9.4 \mathrm{mg}, \%$. It can be assumed that a slight increase in hemoglobin in the blood of broilers of the experimental groups was due to the presence in the studied additive of natural micro and macro elements that affect the hematopoietic function of the organism of broiler chickens (Bakay, 1970; Okolelova, 2006).

An increase in the hemoglobin content in the broiler blood contributes to an increase in the level of redox reactions, to an intensification of the metabolism in the body and, ultimately, to an increase in the growth rate of chickens, which is confirmed by the broiler growth indicators obtained in the studies.

Thus, the data of the conducted studies allow concluding that introduction of hydroponic green feed from barley to broiler fodder according to the developed new feed technology increases the concentration of hemoglobin in blood erythrocytes and increases the use of vitamin A in the bird's body.

\section{Conclusion}

Analyzing the results obtained, the following results can be noted: the introduction of the studied additives in feed in the amount of $15-20 \%$ helps to increase live weight, reduce the content of internal fat by $0.5-1.3 \%$, increase hemoglobin in the blood, vitamin A, carotene, an improvement in fat metabolism in the bird's body, has a positive effect on the meat quality of chickens.

\section{References}

Aii, T., Kurihara, M., Kume, S. (1990). The effect of feeding calcium soap of fatty acids and sodium acetate on the physiological responses of dairy cows. Japanese Journal of Zootechnical Science, 61(10), 959-962.

Bakay, S.M. (1970). Studying technology of cultivation green fodder by hydroponic method. Pig production, 11, 67-68. 
Chuang, W.Y., Hsieh, Y. C., Chen, L.W., Lee, T.-T. (2020). Evaluation of the relationship between adipose metabolism patterns and secretion of appetite-related endocrines on chicken. Animals, 10(8), 1-21. DOI: 10.3390/ani10081282

Elbers, A.R.W., Milterburd, J.D., De Lange, D., Crauwels, A.P.P., Barkema, H.W., Schukken, Y.H. (1998). Risk Factors for Clinical Mastitis in a Random Sample of Dairy Herds from the Southern Part of the Netherlands. Journal of Dairy Science, 81(2), 420-426. DOI: $10.3168 /$ jds.S0022-0302(98)75592-4

Kostyuchenko, V.A. (2010). Agromechanical substantiation of hydroponic green feed production machines: monograph. Kirovograd.

Kruglyakov, Y.A. (1991). Equipment for the continuous hydroponical cultivation of green fodder. Moscow: Agropromizdat.

Matserushka, A.R. (2017). Production and use of hydroponic green forage. Collection of articles in 3 Vol. - XII International scientific-practical conference "Achievements and prospects of production and processing of livestock products", 403.

Okolelova, T.M. (2006). Methodical recommendations. Grain germination and hydroponic production of green fodder. Sergiev Posad.

Saadaoui, I., Cherif, M., Rasheed, R., Hamadou, R.B., Manning, S.R. (2020). Mychonastes homosphaera (Chlorophyceae): A promising feedstock for high quality feed production in the arid environment. Algal Research, 51, 102021. DOI: 10.1016/j.algal.2020.102021

Soliman, F.N.K., El-Sabrout, K. (2020). Light wavelengths/colors: Future prospects for broiler behavior and production. Journal of Veterinary Behavior, 36, 34-39.

Talalay, G.S., Matserushka, A.R. (2017). Ways to increase the digestibility of nutrients in feed in poultry meat farming. Materials of the international scientific-practical conference "Scientific support for the implementation of state programs for agro-industrial complex and rural areas", 597).

Talalay, G.S., Matserushka, A.R. (2020). Utilization efficiency of fodder additives on prepared technology on product quality. Conferinţa știinţifico-practică internaţională/ "Științăa, educație, cultură, Universitatea de stat din comrat, 426-430.

Talalay, G.S., Matserushka, A.R. (2020). Reserves for increasing poultry meat. Conferinţa știinţifico-practică internaţională/ "Știință, educație, cultură, Universitatea de stat din comrat", 430-436. 
IV International Scientific and Practical Conference "Modern S\&T Equipments and Problems in Agriculture"

Ulrikh, E.V., Bagno, O.A., Izhmulkina, E.A., Grachev, S.Y. (2019). Organoleptic and physicochemical properties and safety indicators of phytobiotic fodder additives based on herbal extracts. Prensa Medica Argentina, 105(9), 607-612. 